\title{
SOME REFINEMENTS OF SLATER, PEČARIĆ AND WANG-WANG'S INEQUALITIES
}

\author{
GOU-SHENG YANG AND KUEI-LIN TSENG
}

Abstract. In this article, we establish some refinements of Slater, Pečarić and Wang-Wang's inequalities.

Mathematics subject classification (2000): 26D15.

Key words and phrases: Inequality, geometric mean, harmonic mean, convex function.

\section{REFERENCES}

[1] H. AlZER, An inequality of W. L. Wang and P. F. Wang, Intern. J. Math. and Math. Sci. 13 (2), (1990), 295-298.

[2] J. E. PEČARIĆ, A companion to Jensen-Steffensen's inequality, J. Approx. Theory, 44, (1985), 289-291.

[3] A. W. RoberTs, D. E. VArberg, Convex functions, New York-London, 1973.

[4] M. L. SLATER, A companion inequality to Jensen's inequality, J. Approx. Theory, 32 (1981), 160-166.

[5] W. L. WANG AND P. F. WANG, A class of inequalities for the symmetric functions, Acta Math. Sinica, 27, (1984), 485-497, [In Chinese]. 